\title{
ASI EKSKLUSIF MENINGKATKAN PERKEMBANGAN BAYI USIA 6-12 BULAN DI WILAYAH KERJA PUSKESMAS BANYU URIP SURABAYA
}

\author{
Siti Nurjanah \\ Fakultas Keperawatan dan Kebidanan \\ Universitas Nahdlatul Ulama Surabaya Jl. Smea 57 Surabaya \\ Email : nungj@unusa.ac.id
}

\begin{abstract}
Exclusive Breast Milk Enhances The Development Of Infants Aged 6-12 Months in Region of Puskesmas Banyu Urip Surabaya. Exclusive breastfeedingis only giving breast without other suplemntal food to babies aged 6-12 months. However in factmost mothers do not give breast milk to their childrenby reason of busywork. The purpose of this study to analyzethe relationship between Exclusive Breast Milk enhances the development of infants aged 6-12 months in region of Puskesmas Banyu Urip Surabaya. The type of this research wasanalytic done using by cross sectional design. The population involved themothers having children aged 6-12 monthsand thei rchildren totally 28 respondents, the sample size was 26 respondents taken by using simple random sampling. The data collection using question naires and observation of DDST form. The data processing includes editing, coding, data entry, cleaning, and tabulating. The data were analyzed using the Mann-Whitney statistical testwith asignifican cevalue $\alpha=0,05$. Statistical analysis with the Mann-Whitney was got $\rho=0,000<\alpha=0,05$, whichmeans that $\mathrm{H}_{0}$ isrejectedso that there isa correlation between exclusive breastfeeding. With the Mann-Whitney was got $\rho=0,002<\alpha=0,05$, whichmeans that $\mathrm{H}_{0}$ isrejected so tha there isa correlation between exclusive breastfeeding and the development of children aged 6-12 months in East Java. The conclusions of this research is exclusive breastfeeding is adequate and the developmentof the child within the normal rangesaccording to age. Expectedmothersto breast feed exclusively thoughthe motherwas busyworking, andalwayspay attention totheir children's growth. So as to createa great newgeneration.
\end{abstract}

\begin{abstract}
Abstrak: Asi Eksklusif Meningkatkan Perkembangan Bayi Usia 6-12 Bulan Di Wilayah Kerja Puskesmas Banyu Urip Surabaya. ASI eksklusif adalah pemberian ASI saja tanpa makanan dan minuman tambahan lain pada bayi usia 0-6 bulan. Namun kenyataannya masih banyak ibu yang tidak memberikan ASI eksklusif pada anaknya. Tujuan dari penelitian ini menganalisis pengaruh Asi Eksklusif Meningkatkan Perkembangan Bayi Usia 6-12 Bulan Di Wilayah Kerja Puskesmas Banyu Urip Surabaya. Jenis penelitian ini adalah analitik dengan rancang bangun cross sectional. Populasi seluruh ibu yang memiliki anak usia 6-12 bulan dan anaknya sebesar 28 responden, sampel sebesar 26 responden diambil secara simple random sampling. Pengumpulan data menggunakan kuesioner, pengambilan sampel serta observasi dengan formulir DDST. Pengolahan data meliputi editing, coding, entry data, cleaning, dan tabulating. Analisis data menggunakan uji statistik Mann-Whitney dengan nilai kemaknaan $\alpha=0,05$. Hasil Mann-Whitney didapatkan $\rho=0,000<\alpha=0,05$, yang artinya $\mathrm{H}_{0}$ ditolak sehingga ASI eksklusif mempengaruhi perkembangan anak usia 6-12 bulan. Simpulan pemberian ASI eksklusif yang adekuat akan meningkatkan perkembangan anak sehingga perkembangan sesuai dengan usianya. Diharapkan para ibu dapat memberikan ASI eksklusif yang didukung dengan konsumsi makanan 4 sehat 5 sempurna, meskipun ibu sibuk bekerja, dan selalu memperhatikan serta menstimulasi tumbuh kembang anak.
\end{abstract}


Kata kunci : Pemberian ASI Eksklusif, Perkembangan Anak.

\section{PENDAHULUAN}

Pertumbuhan otak pada anak usia 6-12 bulan merupakan usia pada periode emas dalam kehidupannya, karena pertumbuhan otak di masa ini sangat pesat. Asupan nutrisi yang adekuat sangat penting untuk menstimulasi pertumbuhan otak yang adekuat. Pertumbuhan otak selain diperoleh saat dalam kandungan juga di dapat setelah anak dilahirkan sampai usia 5 tahun.. Pertumbuhan otak yang optimal akan mempengaruhi perkembangan dan kecerdasan anak. (Widodo Judarwanto dalam www.kompas.com). Bayi berusia 0-6 bulan membutuhkan ASI secara eksklusif, karena pencernaan bayi belummampu untuk mendapat makanan tambahan. Masyarakt di Jawa Timur sebagian besar sudah memberikan makanan tambahan sejak usia dini atau sebelum usia 6 bulan, dengan alasan anak sering rewel, cepat gemuk dan alasan lainnya adalah air susu tidak keluar (Wardana, 2012). Pemberian ASI saja tanpa makanan pendamping apapun sampai bayi berusia enam bulan akan mempunyai manfaat yang luar biasa bagi perkembangan dan pertumbuhan bayi (Sri Purwanti, 2004). Keberhasilan tiap fase tumbuh kembang ternyata berpengaruh terhadap kemampuan seseorang di fase selanjutnya. Setiap orang tua tentunya sangat menginginkan anak-anaknya dapat tumbuh dan berkembang secara optimal di setiap tahun usianya, sehingga memantau tumbuh kembang putraputrinya merupakan sebuah keinginan bahkan "keharusan" (Sulistyawati, 2014).

Berdasarkan data dari dinas kesehatan provinsi Jawa Timur cakupan pemberian ASI eksklusif pada tahun 2010 sekitar 31,2\%, sedangkan pada tahun 2011 cakupan pemberian ASI eksklusif mengalami peningkatan yakni $61,52 \%$, namun hal ini masih jauh dari target cakupan ASI eksklusif di Indonesia yakni 80\% (Dinkes, 2012). Berdasarkan hasil survei pendahuluan melalui wawancara yang telah dilakukan peneliti pada April 2014 ada 38 orang, didapatkan 8 ibu yang memberikan ASI eksklusif, dan 23 orang tidak memberikan ASI eksklusif kepada anaknya dengan alasan ibu bekerja, 5 orang dengan alasan ASI tidak keluar, 2 orang dengan alasan bayinya tidak diasuh oleh ibunya. Terdapat $19 \%$ di Jawa Timur bayi yang mengalami keterlambatan perkembangan pada bayi. (Laporan Data Dinas Kesehatan Jawa Timur tahun 2014)

Beberapa faktor yang mempengaruhi tumbuh kembang yaitu faktor herediter (bawaan, jenis kelamin, ras, dan suku bangsa) dan faktor lingkungan meliputi faktor lingkungan pranatal (gizi pada waktu ibu hamil, mekanis, toksin atau zat kimia, endokrin, radiasi, infeksi, stress, imunitas dan anoksia embrio) dan faktor lingkungan postnatal (budaya, status sosial ekonomi, asupan nutrisi seperti pemberian ASI eksklusif, iklim dan cuaca, olahraga atau latihan fisik, posisi anak dalam keluarga, status kesehatan), serta faktor hormonal (Hidayat, 2008). Ketidakefektifan waktu ibu untuk menyusui bayinya menjadi penghalang pemberian ASI eksklusif yang akan berpengaruh pada tumbuh kembang sang anak.

Dampak jika bayi tidak mendapatkan ASI Eksklusif yakni daya tahan tubuh atau antibodi kurang sempurna, sehingga bayi rentan terhadap timbulnya penyakit, perkembangan otak atau kecerdasan otak kurang optimal, perkembangan motorik mengalami keterlambatan, dampak psikologis kedekatan dengan ibu kurang opotimal dan asupan nutrisi bayi kurang terpenuhi (wordpress, 2012). Bayi yang mendapatkan ASI secara eksklusif akan mengalami pertumbuhan dan perkembangan yang optimal. Pertumbuhan yang optimal dapat dilihat dari penambahan berat, tinggi badan ataupun lingkar kepala, sedangkan 
perkembangan yang optimal dapat dilihat dari adanya peningkatan kemampuan motorik kasar, psikomotorik dan bahasa (Sulistyoningsih, 2011). Perkembangan anak usia dini harus mendapat perhatian yang serius. Upaya ke arah sana tentunya memerlukan berbagai dukungan, terutama dukungan dalam aspek gizi, kesehatan, dan pendidikan. Ketiga aspek tersebut merupakan pilar utama pengembangan anak usia dini, sebab memberi pengaruh yang besar terhadap kualitas anak di masa yang akan datang (Jalal, 2002). Biasanya bayi yang sudah diberi makanan setengah padat pada umur kurang dari 4 bulan akan menyusu lebih sedikit. Hal ini disebabkan ukuran perut bayi masih kecil sehingga mudah penuh, sedangkan kebutuhan gizi bayi belum terpenuhi. Hal ini mengakibatkkan pertumbuhan dan perkembangan bayi akan terganggu. Sebaliknya apabila bayi yang berumur lebih dari 6 bulan belum mengenal makanan lain selain ASI, pertumbuhan dan perkembangannya tidak akan mengalami gangguan (Krisnatuti, 2004).

Pada hakekatnya air susu ibu (ASI) bisa diberikan baik secara langsung maupun tidak langsung. Pemberian ASI secara tidak langsung dapat diberikan dengan cara diperah atau dipompa, kemudian disimpan dalam botol dan diberikan pada bayi secara langsung ataupun menyimpannya dalam lemari es. Sehingga pemberian ASI sampai enam bulan tetap dapat dilaksanakan tanpa harus memberi makanan dan minuman pendamping selain ASI. Petugas kesehatan juga mempunyai tanggung jawab terhadap pelayanan kesehatan ibu dan anak, pemberian ASI segera setelah bayi lahir, mengajarkan ibu cara menyusui yang benar dan memberikan informsi tentang managemen laktsi yaitu memberikan penyuluhan dan pemahaman terhadap ibu tentang pentingnya ASI eksklusif saat kunjungan rutin ibu nifas sehingga ibu menyadari dan merasakan bangga dan bahagia serta prospek dalam menyusui bayinya (Hubertin, S.P, 2004)

Peneliti tertarik untuk mengadakan penelitian dengan judul "Hubungan antara pemberian ASI eksklusif dengan perkembangan anak usia 6-12 bulan di wilayah Jawa Timur". Penelitian ini bersifat analitik dengan menyelidiki kemungkinan adanya hubungan antara pemberian ASI eksklusif dengan perkembangan anak usia 6-12 bulan.

\section{METODE PENELITIAN}

Desain penelitian yang digunakan dalam penelitian ini bersifat analitik observasional dimana peneliti hanya mengamati tanpa memberikan intervensi terhadapp objek dengan mengggunakkan pendekatan secara crooss sectional, Populasi dalam penelitian ini adalah seluruh ibu yang memiliki anak usia 612 bulan dan anaknya di Wilayah Kerja Puskesms Banyu Urip Surabaya dengan besar populasi 28 orang. Sampel penelitian ini adalah sebagian ibu yang memiliki anak usia 6-12 bulan dan anaknya di wilayah kerja Puskesmas Banyu Urip Surabaya. Teknik pengambilan sampel yang digunakan adalah menggunakan metode probability sampling. Cara pemilihan sampel dengan teknik simple random sampling. .Cara pengumpulan data yang digunakan dalam penelitian ini adalah menggunakan kuesioner yang akan dijawab oleh ibu melalui wawancara tentang pemberian ASI eksklusif, sedangkan lembar DDST diisi oleh peneliti ketika melakukaan penilaian terhadap perkembangan anak usia 6-12 bulan dengan memberi stimulasi permainan pada anak. Analisis data merupakan proses atau analisa yang dilakukan secara sistematis terhadap data yang telah dikumpulkan dengan tujuan untuk mengetahui hubungan antara dua variabel. Data yang sudah terkumpul kemudian dianalisis dengan uji MannWhitney pada tingkat kemaknaan $\alpha=0,05$ dengan bantuan SPSS For Windows, sehingga diperoleh, jika probabilitas $<0,05$ atau $\mathrm{p}<\alpha$, maka $\mathrm{H}_{\mathrm{o}}$ ditolak berarti 
ada hubungan antara ASI eksklusif dengan perkembangan anak usia 6-12 bulan di wilayah Jawa Timur.

\section{HASIL PENELITIAN}

a. Pemberian ASI eksklusif

Tabel 1: Distribusi frekuensi responden berdasarkan pemberian ASI eksklusif di wilayah Kerja Puskesmas Banyu Urip Surabaya pada bulan Januari-Juni 2015

\begin{tabular}{cccc}
\hline No & $\begin{array}{c}\text { Pemberian } \\
\text { ASI }\end{array}$ & Frekuensi & $\begin{array}{c}\text { Persentase } \\
(\%)\end{array}$ \\
\hline 1 & $\begin{array}{c}\text { ASI eksklusif } \\
\text { Tidak ASI } \\
\text { eksklusif }\end{array}$ & 7 & 26,92 \\
2 & Jumlah & 26 & 73,08 \\
\hline & 19 & 100,00 \\
\hline
\end{tabular}

Sumber : Data primer 2015

Berdasarkan tabel diatas menunjukkan bahwa dari 26 responden didapatkan sebagian besar $(73,08 \%)$ ibu tidak memberikan ASI eksklusif kepada anaknya.

a. Perkembangan anak

1) Personal sosial anak

Tabel 2: Distribusi frekuensi responden berdasarkan perkembangan personal sosial anak usia 6-12 bulan di wilayah Kerja Puskesmas Banyu Urip Surabaya pada bulan Januari-Juni 2015

\begin{tabular}{cccc}
\hline No. & $\begin{array}{c}\text { Perkembangan } \\
\text { personal sosial } \\
\text { anak }\end{array}$ & $\begin{array}{c}\text { Frekue } \\
\text { nsi }\end{array}$ & $\begin{array}{c}\text { Persent } \\
\text { ase }(\%)\end{array}$ \\
\hline 1 & Normal & 19 & 73,08 \\
2 & Suspek & 7 & 26,92 \\
3 & Untestable & 0 & 00,00 \\
\hline & Jumlah & 26 & 100,00 \\
\hline
\end{tabular}

Sumber : Data primer 2015

Berdasarkan tabel diatas menunjukkan bahwa dari 26 responden didapatkan sebagian besar $(73,08 \%)$ perkembangan personal sosial anak dalam kategori normal

2) Motorik halus anak

Tabel 3: Distribusi frekuensi responden berdasarkan perkembangan motorik halus anak usia 6-12 bulan di wilayah Kerja
Puskesmas Banyu urip Surabaya pada bulan Januari-Juni 2015

\begin{tabular}{cccc}
\hline No. & $\begin{array}{c}\text { Perkembangan } \\
\text { mootorik halus } \\
\text { anak }\end{array}$ & $\begin{array}{c}\text { Freku } \\
\text { ensi }\end{array}$ & $\begin{array}{c}\text { Persenta } \\
\text { se }(\%)\end{array}$ \\
\hline 1 & Normal & 14 & 53,85 \\
2 & Suspek & 12 & 46,15 \\
3 & Untestable & 0 & 00,00 \\
\hline & Jumlah & 26 & 100,00 \\
\hline
\end{tabular}

Sumber : Data primer 2015

Berdasarkan tabel diatas menunjukkan bahwa dari 26 responden didapatkan sebagian besar $(53,85 \%)$ perkembangan motorik halus anak dalam kategori normal.

3) Bahasa anak

Tabel 4 : Distribusi frekuensi responden berdasarkan perkembangan bahasa anak usia 6-12 bulan di wilayah Kerja Puskesmas Banyu Urip Surabaya pada bulan Januari-Juni 2015

\begin{tabular}{cccc}
\hline No. & $\begin{array}{c}\text { Perkembangan } \\
\text { bahasa anak }\end{array}$ & $\begin{array}{c}\text { Frekue } \\
\text { nsi }\end{array}$ & $\begin{array}{c}\text { Persenta } \\
\text { se }(\%)\end{array}$ \\
\hline 1 & Normal & 6 & 23,08 \\
2 & Suspek & 20 & 76,92 \\
3 & Untestable & 0 & 00,00 \\
\hline & Jumlah & 26 & 100,00 \\
\hline
\end{tabular}

Sumber : Data primer 2015

Berdasarkan tabel diatas menunjukkan bahwa dari 26 responden didapatkan hampir seluruhnya $(76,92 \%)$ perkembangan bahasa anak dalam kategori suspek.

4) Motorik kasar anak

Tabel 5: Distribusi frekuensi responden berdasarkan perkembangan motorik kasar anak usia 6-12 bulan di wilayah Kerja Puskesmas Banyu Urip Surabaya pada bulan Januari-Juni 2015

\begin{tabular}{cccc}
\hline No. & $\begin{array}{c}\text { Perkembangan } \\
\text { motorik kasar anak }\end{array}$ & $\begin{array}{c}\text { Freku } \\
\text { ensi }\end{array}$ & $\begin{array}{c}\text { Persentase } \\
(\%)\end{array}$ \\
\hline 1 & Normal & 5 & 19,23 \\
2 & Suspek & 21 & 80,77 \\
3 & Untestable & 0 & 00,00 \\
\hline & Jumlah & 26 & 100,00 \\
\hline
\end{tabular}


Sumber : Data primer 2015

Berdasarkan tabel diatas menunjukkan bahwa dari 26 responden didapatkan hampir seluruhnya $(80,77 \%)$ perkembangan mootorik kasar anak dalam kategori suspek.

Tabel 6: Tabulasi silang pemberian ASI eksklusif dengan perkembangan anak usia 6-12 bulan di wilayah Kerja Puskesmas Banyu Urip Surabaya pada bulan Januari-Juni 2015.

\begin{tabular}{lccccccc}
\hline \multirow{2}{*}{$\begin{array}{c}\text { Pemberia } \\
\text { n ASI }\end{array}$} & \multicolumn{6}{c}{ Perkembangan Anak } & \\
\cline { 2 - 7 } & \multicolumn{2}{c}{ Normal } & \multicolumn{2}{c}{ Suspek } & \multicolumn{2}{c}{$\begin{array}{c}\text { Untesta } \\
\text { ble }\end{array}$} & \\
\cline { 2 - 7 } & $\mathrm{N}$ & $\%$ & $\mathrm{~N}$ & $\%$ & $\mathrm{~N}$ & $\%$ & $\%$ \\
\hline ASI & 6 & 85, & 1 & 14, & 0 & 00, & 100, \\
eksklusif & & 71 & & 29 & & 00 & 00 \\
Tidak & & 26, & & 73, & & 00, & 100, \\
ASI & 5 & 32 & 14 & 68 & 0 & 00 & 00 \\
eksklusif & & 42, & & 57, & & 00, & 100, \\
Jumlah & 11 & 31 & 15 & 69 & 0 & 00 & 00 \\
\hline
\end{tabular}

Sumber : Data primer 2015

Berdasarkan tabel diatas menunjukkan bahwa dari 7 responden yang memberikan ASI eksklusif hampir seluruh $(85,71 \%)$ perkembangan anak dalam kategori normal. Dan dari 19 responden yang tidak memberikan ASI eksklusif sebagian besar $(73,68 \%)$ perkembangan anak dalam kategori suspek.

Hasil uji statistik Mann-Whitney, didapatkan $\rho=0,022<\alpha=0,05$ sehingga $\mathrm{H}_{0}$ ditolak yang artinya ada hubungan antara pemberian ASI eksklusif dengan perkembangan anak usia 6-12 bulan di wilayah Jawa Timur.

\section{PEMBAHASAN}

\section{Pemberian ASI Eksklusif}

Berdasarkan hasil penelitian menunjukkan bahwa dari 26 responden sebagian besar $(73,08 \%)$ ibu tidak memberikan ASI eksklusif pada anaknya. Banyaknya ibu yang tidak memberikan ASI eksklusif pada anaknya karena ungkapan dari responden sebgaian besar karena kesibukan ibu sebagai seorang yang bekerja di luar rumah, serta ibu merasa ASI saja tidak dapat memenuhi kebutuhan anak yang dikarenakan sang anak selalu rewel, ditunjang dengan tingkat pengetahuan dari ibu, pengasuh dan nenek serta suaminya kurang baik, sehingga ada kecenderungan ibu memberikan makanan pendamping ASI seperti susu formula, nasi dilotek pisang, atau nasi tim pada anak yang usianya kurang dari 6 bulan. Anak yang usianya kurang dari 6 bulan cukup diberikan ASI saja, karena pada usia tersebut pencernaan sang anak masih belum sempurna untuk mencerna makanan dan minuman lain selain ASI, sehingga dapat menimbulkan berbagai penyakit. Hal ini sesuai dengan teori Prasetyono (2012), bahwa ASI bisa menurunkan dan mencegah terjadinya penyakit infeksi dan noninfeksi, seperti penyakit alergi, obesitas, kurang gizi, asma, dan eksem. Selain itu, ASI dapat pula meningkatkan IQ dan EQ anak. Makanan Pendamping ASI sebaiknya diberikan pada bayi yang berusia lebih dari 6 bulan, dan ASI tetap diberikan sampai bayi berusia 2 tahun.

Berdasarkan hasil penelitian menunjukkan hampir seluruh $(92,30 \%)$ ibu bekerja di luar rumah. Ibu yang bekerja dapat memerah ASI meskipun sedang bekerja, namun karena ibu tidak mempunyai ide, malas, capek bekerja dan kurangnya pengetahuan sehingga sebagian besar responden tidak memberikan ASI secara eksklusif pada anaknya. Hal ini sesuai dengan teori (Kristiyansari, 2009) bahwa bagi ibu yang bekerja, menyusui tidak perlu dihentikan. Ibu bekerja tetap harus memberikan ASI kepada bayinya. Ibu dapat memerah ASI 2-3 kali (setiap 3 jam), simpan ASI di lemari es dan dibawa pulang dengan termos es saat ibu selesai bekerja.

Usia mempengaruhi seseorang untuk memberikan ASI eksklusif pada anaknya. Hal ini bisa dilihat pada hasil 
penelitian bahwa sebasgian besar $(73,08 \%)$ ibu berusia antara 20-40 tahun dan sebagian besar adalah primigravida. Pada usia tersebut ibu dapat dikatakan siap dari segi psikologis yang sudah dewasa dan dari segi fisik dimana usia tersebut dalam kategori usia produktif yang idealnya tidak sulit untuk mmemberikan ASI eksklusif pada anaknya. Begitu juga dengan pengalaman pertama mempunyai anak, hal tersebut membuat ibu mempunyai motivasi yang tinggi untukemberikan ASI secara eksklusif. Hal ini tidak sesuai dengan pendapat Papilia (2009), usia seseorang akan mempengaruhi pola pikir dan sikap seseorang dalam mengolah dan menggunakan penalaran ilmiah yaitu dalam hal ini sikap dan perilaku ibu terhadap pemberian ASI eksklusif pada bayi. Pengalaman pertama membuat seorang ibu untuk mematuhi kebijakan yang ada terutama dari pemerintah (Papilia, 2009)

\section{B. Perkembangan Anak}

Berdasarkan tabel 5. menunjukkan bahwa dari 26 responden didapatkan hampir seluruhnya $(80,77 \%)$ perkembangan mootorik kasar anak dalam kategori suspek. Hal ini dapat disebabkan kurangnya intensitas waktu ibu dalam memberikan stimlasi perkembangan pada anaknya karena sibuk bekerja. Waktu pemberian stimulasi perkembangan motorik sangatlah diperlukan saat anak dalam keadaan aktif, sedangkan saat itu ibu siuk bekerja. Akibatnya ibu tidak dapat secara optimal untuk memberikan stimulasi pada anak. Sehinngga perkembangan motorik anak dapat mengalami keterlambatan. Hal ini didukung teori yang dikemukakan oleh Sulistyo (2011), bahwa status pekerjaan ibu mempengaruhi jumlah waktu yang dimiliki ibu dalam melaksanakan fungsinya sebagai ibu rumah tangga, dimana ibu yang bekerja akan terbagi waktunya oleh tanggung jawab di luar fungsinya sebagai ibu rumah tangga.

Faktor lain yang mempengaruhi perkembangan anak adalah kedudukan anak dalam keluarga. Ibu muda yang baru mempunyai anak akan kurang berpengalaman untuk memberikan asuhan pada bayinya, sehingga ibu juga tidak mengerti cara memberi stimulasi perkembangan sesuai usia anak. Sehingga anak dapat mengalami keterlambatan dalam perkembangannya. Sesuai Notoadmodjo (2010), pengalaman merupakan sumber pengetahuan atau suatu cara untuk memperoleh kebenaran, oleh sebab itu pengalaman pribadi dapat digunakan sebagai upaya memperoleh pengetahuan.

Faktor berikutnya adalah pendidikan. Berdasarkan Ibu yang berpendidikan menengah cukup dapat menangkap informasi dan edukasi yang telah diberikan petugas kesehatan mengenai cara dan manfaat pemberian stimulasi perkembangan pada anak. Hal ini sesuai dengan teori yang dikemukakan oleh Nursalam (2008), bahwa semakin tinngi tingkat pendidikan seseorang maka semakin mudah pula kemampuan seseoarang dalam menerima informasi sehingga semakin banyak pengetahuan yang dimiliki.

\section{Hubungan Pemberian ASI Eksklusif dengan Perkembangan Anak}

Hasil uji statistik Mann-Whitney pemberian ASI eksklusif dengan perkembangan anak dengan nilai kemaknaan $\alpha=0,05$ diperoleh hasil perhitungan $\rho=0,022$, artinya $\mathrm{H}_{0}$ ditolak maka ada hubungan pemberian ASI eksklusif dengan perkembangan anak usia 6-12 bulan di wilayah kerja Puskesmas Banyu urip Surabaya. .

Berdasarkan tabel 6 menunjukkan bahwa dari 7 responden yang memberikan ASI eksklusif hampir seluruhnya $(85,71 \%)$ perkembangan anak dalam kategori normal. Hal tersebut dikarenakan bayi mendapatkan ASI 
eksklusif yang mengandung taurin, decosahexanoic acid (DHA), arachidonic acid (AA), Imunoglobin A (Ig A), Imunoglobin G (Ig G), lactoferin, lysozim enzyme, karbohidrat, protein, vitamin, dan lain-lain untuk memenuhi kebutuhan bayi. Selain itu tidak terbentuknya bounding attachment antara ibu dan bayi saat proses menyusui, yaitu memberikan kesempatan bagi ibu untuk lebih dekat dengan bayi melalui rangsangan tubuh yang diberikan oleh ibu pada bayi. Hal ini sesuai teori yang dikemukakan oleh Diah (2012), bahwa keuntungan dari pemberian ASI eksklusif adalah bayi mengalami pertumbuhan dan perkembangan yang sesuai dengan umur, terbentuknya ikatan batin yang kuat, serta meminimalkan resiko bayi terserang penyakit pencernaan, pernafasan, dan lain-lain.

Pemberian ASI akan lebih efektif jika ibu mempunyai waktu yang lama saat menyusui, karena ada proses interaksi ketika proses menyusui yang memungkinkan ibu memberikan stimulus pada bayi melalui dekapan, kontak mata, komunikasi antara ibu dan bayi, upaya ibu untuk menenangkan bayi saat menangis dan upaya bayi mancari puting susu ibu, sehingga terjalin bounding attechment. Hal ini sesuai dengan teori Fitria (2012), bounding attachment dapat diperoleh dari menyusui, hal ini memberikan kesempatan ibu untuk memberikan stimulus terhadap bayi melalui cara menyentuh bayi, memasukkan puting susu pada mulut bayi, tercipta kontak mata, interaksi ibu terhadap bayi sehingga perkembangan anak dapat normal sesuai usianya.

\section{SIMPULAN}

Berdasarkan hasil penelitian dan pembahasan mengenai hubungan antara pemberian ASI eksklusif dengan peerkembangan anak usia 6-12 bulan di Jawa Timur disimpulkan sebagai berikut : a. Ibu yang memiliki anak usia 6-12 bulan sebagian besar ibu tidak memberikan ASI eksklusif pada anaknya di wilayah kerja Puskesmas Banyu Urip Surabaya.

b. Perkembangan bayi usia 6-12 bulan di wilayah kerja Puskesmas Banyu Urip Surabaya sebagian besar dalam kategori suspek.

c. Ada hubungan antara ASI eksklusif dengan perkembangan anak usia 612 bulan di wilayah kerja Puskesmas Banyu Urip Surabaya.

\section{DAFTAR PUSTAKA}

Adriana, D (2011). Tumbuh Kembang dan Terapi Bermain pada Anak. Jakarta : Salemba Medika

Arikunto, Suharsimi. (2010). Prosedur Penelitian Suatu Pendekatan. Jakarta : Rineka Cipta

Aziz, Alimul Hidayat. (2008). Pengantar Ilmu Kesehatan Anak untuk Pendidikan Bidan. Jakarta: Salemba Medika.

Diah, (2012). Pengertian ASI Eksklusif dan Manfaat ASI Eksklusif. Dalam www.jurnalbidan.com. Artikel diakses tanggal 18 Mei 2013

Dinkes Prov Jatim, (2012). Profil Dinas Kesehatan Provinsi Jawa Timur 2012. Jakarta, Dinas Kesehatan

Depkes RI, (2006). Pedoman Pemberian MP-ASI Lokal. Surabaya, Bakti Husada

Depkes RI, (2006). Stimulasi Deteksi dan Intervensi Dini Tumbuh Kembang Anak. Jakarta, Depkes RI

Fitria (2012). Hubungan Bounding Attachment dengan Perkembangan Bayi. Dalam www.fitmidwife.com, d8iakses tanggal 25 Juni 2013

Hubertin SP, (2004). Konsep Penerapan ASI Eksklusif. Buku Saku Untuk Bidan. Jakarta : EGC

Krisnatuti, Diah (2004). Menyiapkan Makanan Pendamping ASI. Jakarta : Puspa Swara 
Kristiyanasari, Weni (2009). ASI Menyusui dan SADARI. Jogjakarta : Nuha Medika

Laksono, Kodrat (2010). Dahsyatnya ASI dan Laktasi. Jakarta : Media Baca

Marimbi, Hanum (2010). Tumbuh Kembang Status Gizi dan Imunisasi Dasar pada Balita. Jakarta : Nuha Medika

Muslihatun, Wafi Nur (2010). Asuhan Neonatus, Bayi dan Balita cetakan Pertama. Jogjakarta : Penerbit Fitramaya

Nanny, Vivian (2010). Asuhan Neonatus Bayi dan Anak Balita. Jakarta : Salemba Medika

Nursalam. (2008). Konsep dan Penerapan Metodologi Penelitian Ilmu Keperawatan. Jakarta: Salemba Medika.

Nurul (2012) Ektraks daun katu (Sauropus Androgynus). L (Merr) memepengaruhi peningkatan kadar hormone prolaktin tdan peningkatan pertumtubuhan sel neuralgia anak tikus. Universitas Airlangga Surabaya.

Prasetyono, DS (2009). Buku Pintar ASI Eksklusif. Jogjakarta :DIVA Press (Anggota IKAPI)

Purnamasari, Ariavita ed (2006). Kamus Perkembangan Bayi dan Balita. Jakarta : ESENSI

Riksani, Ria (2011). Keajaiban ASI. Jakarta Timur : Dunia Sehat
Roesli, Utami (2005). Mengenal ASI Eksklusif. Jakarta : Trubus Agriwidya

Rohani, (2007). ASIku untuk Anakku. Dalam www.anakku.net. Artikel yang diakses tanggal 11 Juni 2013

Saleha, Sitti (2009). Asuhan Kebidanan pada Masa Nifas. Jakarta :Salemba Medika

Santoso, Heru W (2009). Petujnjuk Praktis Denver Developmental Screening Test. Jakarta :Penerbit Buku Kedokteran EGC

Soetjiningsih, (2005). ASI Petunjuk Untuk Tenaga Kesehatan. Jakarta :EGC

Soetjiningsih, (1995). Tumbuh Kembang Anak. Jakarta : EGC (Cetakan 2012)

Suherni, dkk (2008). Perawatan Masa Nifas. Jogjakarta : Fitramaya

Sulistyo, Dwi Cahyaningsih (2011). Pertumbuhan dan Perkembangan Anak dan Remaja. Jakarta : Trans Info Mediia

Sulistyoningsih, Hariyani. (2011). Gizi Untuk Ibu Dan Anak. Jogjakarta : Graha Ilmu

Tirtaraharda Umar, dkk (2005). Pengantar Pendidikan. Jakarta : Rineka Cipta 